\title{
Effect of Sun-drying on proximate composition and pH of Shoal fish (C. striatus; Bloch, 1801) treated with Salt and Salt-turmeric storage at Room Temperature $\left(27^{0}-30^{\circ} \mathrm{C}\right)$
}

\author{
Farzana Binte Farid*, Gulshan Ara Latifa, Mosarrat Nabila Nahid \\ and Mohajira Begum ${ }^{1}$ \\ Department of Zoology, University of Dhaka, Dhaka 1000, Bangladesh, \\ ${ }^{I}$ Institute of Food Science and Technology, BCSIR, Dhaka 1205, Bangladesh.
}

\begin{abstract}
Sun-drying is one of the most important low-cost methods of fish-preservation and the products provide nutrients to all categories of people through the world including Bangladesh. The study was conducted to obtain a better understanding difference between sun-dried salted (SDS) and turmeric treated sun-dried salted $(S D S+T)$ Shoal fish-product in laboratory-condition by analyzing proximate-composition and $p H$ using standard methods of analyses. In fresh-process condition, the values of moisture (\%), protein (\%), fat $(\%$, ash (\%)and $\mathrm{pH}$ value were $29.77 \%, 41.48 \%, 5.10 \%, 22.80 \%$ and 6.2 in case of SDS Shoal fish and $30.92 \%, 41.0 \%$, $4.79 \%, 22.41 \%$ and 6.3 respectively in case of SDS + T Shoal fish product. During storage period, the values of moisture (\%) and $p H$ were significantly $(p<0.05)$ increased $35.26 \%$ and 8.3 in SDS (165 days) and $36.98 \%$ and 8.2 in SDS $+T$ (180 days) respectively. The values of protein (\%), fat (\%) and ash (\%) content were significantly $(p<0.05)$ decreased $38.62 \%, 3.81 \%$ and $21.44 \%$ respectively in case of SDS Shoal (165 days) and 38.01\%, $3.26 \%$ and $21.07 \%$ (180 days) respectively in case of SDS $+T$ Shoal fish. Experimentally it has been proved that the fishes preserved in $S D S+T$ has longer shelf life and has found better way for preservation.
\end{abstract}

Key Words: Proximate-composition, $p H$, Sun-dried-salting, Shoal, Turmeric-treated-sun-dried-salting.

\section{Introduction}

Nutritional studies have proved that fish protein rank in the same class as chicken protein and are superior to beef protein, milk and egg albumin [1]. Furthermore, fish is rich in protein with amino acid composition which is essential for the maintenance of a healthy body.[2, 3, 4].

Among the good quality animal protein sources, fish is the most perishable. Fish is the most susceptible animal to autolysis, oxidation and hydrolysis of fats and microbial spoilage [5]. The deterioration is believed to cause mainly by the bacterial activity, which brings about very noticeable changes in the texture, flavor, odor and general appearance of the product. The microorganisms present on fish include those which are associated with the raw material and acquired during harvesting, handling and processing [6,7]. Fishes are in constant interaction with microorganisms which cause spoilage and their metabolic activities result in the appearance of slime, gross discoloration and strong odors and which become offensive to customers $[8,9]$.

Fish processing has been practiced in Bangladesh for a long time, simplest method employed are drying, salting and semi-fermentation. The process of fish drying involves the removal of moisture from fish flesh; this could be achieved through sun-drying, smoke-drying, application of pressure and use of absorbent pads. Sun drying is presumably the oldest method of fish preservation employing hot heat from sun and atmospheric air [10]

A bulk of the total artisanal marine sector is being utilized for production of traditional dried products. Drying, the oldest, easiest and excellent way of fish processing has been introduced in our country by the Arabian saints and businessmen who have been believed to be pioneer in the production and marketing of dried fish products throughout the world since the Egyptian civilization [11]. Presently this low-cost, simple and popular fish processing method is being practiced extensively in our country as well as throughout the world. Although dried fishes do not give similar flavor, taste or texture of fresh fish, it is liked and consumed by a large number of people of the world due to characteristic taste and flavor developed in the dried fishery products during drying process. Dried fish is an important source of animal protein is providing nutrition of the poor and economically disadvantaged people of Bangladesh. Today, dried fish has become accepted in most people's diets. It is no longer considered a poor man's dish and some dried fish are served as a snack in bars and hotels.

According to local estimate artisanal catch comprises $95 \%$ of the total marine catch in our country of which $20 \%$ is being sun-dried and consumed in the domestic market [12]. Bangladesh earns a significant amount of foreign currency by exporting dried fish and fishery products which ranks third in the export item.

\footnotetext{
${ }^{*}$ To whom communication should be made, e-mail: farzanafarid79@gmail.com
} 
Bangladesh earned about taka 3.71 crore as foreign currency by exporting about 272 tons of dried fish and fishery products in 2004-2005[13].

In addition, the annual fish harvest fluctuates seasonally, with periods of high and low supply. During the periods of high supply, a lot of fish is spoiled and washed. It is estimated that about 30\% ( about 3,07,500 $\mathrm{mt}$ ) of the freshly harvested fish are spoiled every year due to lack of poor processing and preservation at artisanal fishermen level, while acute shortage and increase costs of fish are experienced in periods of low harvest [14].

In order to reduce the wastage and spoilage of fish during periods of oversupply, and to enhance long storage, it is necessary to adopt appropriate as well as affordable processing and preservation techniques for fish especially in the artisanal fisherman's environment.

In the traditional storage of dried fish in Bangladesh, no proper measures are normally taken to protect the fish against unfavorable environmental conditions. Dry fishes are normally kept in gunny bags or in bamboo baskets. In the humid months during the monsoon, the average relative humidity in Bangladesh is over $85 \%$. Dried fish in this period absorbs moisture from air, resulting in a higher water activity which is favorable for microbial growth.

Therefore, alternative affordable, safe, hygienic and environmental friendly methods must be developed and adopted for fish drying. In this study salt and turmeric are also used with sun drying as a preservative. Sodium chloride $(\mathrm{NaCl})$, also called common salt, and table salt, is generally recognized as a safe, antimicrobial and incidental food additive [15]. Salt has been used as a seasoning and flavor enhancer as well as a preservative or curing agent, had been purchased from the local market. Salt is a powerful depressor of water activity $\left(\mathrm{a}^{\mathrm{w}}\right)$ of the food [16]. Moreover, it is known that chloride ions are toxic for some microorganisms [17]. Although, large amounts of salt give fish a very salty taste. At the same time many of the nutrients are lost if too much salt is used.

Turmeric is one of the oldest known anti-bacterial ingredients used by the ancient civilizations. In Bangladesh, turmeric is cheap, easily available and is considered as one of the important ingredient for cooking any kind of dish. Even in some parts of Bangladesh, rural people usually use turmeric for short time preservation of small sized fishes. But the scientific information's about the use of turmeric in fish preservation are totally absent.

Fresh, dried and powered form of turmeric is used as a newly introduced element in salt curing method with a hypothesis that it would work as protection against insect, pest, fungus and other pathogens and also a longer term preserver.

Biochemical quality assessments are necessary to ensure the food safety of any processed products. Only few studies on the biochemical and nutritional changes are available during dehydration [18]. But, no literature is found about sun-dried salted and turmeric treated sun-dried salted fresh water fish.

\subsection{Collection of the fishes and location of the experiment:}

\section{Materials And Methods}

The raw fish (Shoal) had been collected from the river Meghan in the early hours of the day and the fishes were brought to the Fish Technology Section, IFST, BCSIR, Dhaka for conducting the research activities, starts in the month of January, 2014. The whole experimental period covered 6 months of duration started from January, 2014 to July, 2014.

\subsection{Preparation of fish:}

The fishes were carefully washed with cooled tap water. Head, scales, fins, gills and viscera were removed and again washed with tap water to remove blood, slime and unnecessary flesh. Because of hard and large bones of the head, the bones and head of Shoal are included as the waste.

\subsection{Fresh Sample:}

A fresh flesh sample of shoal fish species was taken to the laboratory for quality analysis. 6 or 7 slice was taken randomly which represented the parts from whole body of the fish. Then the slices were chopped with skin and bone and finally ground with an electric blender to make a homogenous sample before being sampled for analysis.

\subsection{Sun-dried-salt curing method:}

During this experiment the raw fishes were enrolled by dry commercial salt $(\mathrm{NaCl})$ of about $30 \%$ by weight of the dressed fish (fish weight: salt weight 3:1). They were kept on a plastic bade basket in the sun. They were kept in sun regularly during day time (12 a.m. to 3 p.m.) for 2-7 days as sometimes the sky was cloudy and until the ripening period was over. At the same time, temperature and relative humidity were also recorded. During sun-drying, they were kept covered by dense meshed nylon or mosquito net to avoid outside contamination and prevent bird attack and fly infestation. 


\subsection{Turmeric treated sun-dried-salt curing method:}

During this experiment the raw fishes were enrolled by dry commercial salt $(\mathrm{NaCl})$ of about $30 \%$ by weight of the dressed fish (fish weight: salt weight 3:1) and Turmeric powder of about $1 \%$ of dressed fish weight. They were kept on a plastic bade basket in the sun. They were kept in sun regularly during day time (12 a.m. to 3 p.m.) for 2-7 days until the ripening period was over. At the same time, temperature and relative humidity were also recorded. During sun-drying, they were kept covered by dense meshed nylon or mosquito net to avoid outside contamination and prevent bird attack and fly infestation.

\subsection{Sampling procedures:}

Evaluation of physical and biochemical changes in sun-dried- salted and turmeric treated Sun-Dried Salted shoal fishes were carried out 15 days interval for the room temperature $\left(27^{0} \mathrm{C}-30^{\circ} \mathrm{C}\right)$ until the fish become spoil or inedible condition. Two duplicate experiments were conducted at regular time intervals during salting period.

6 or 7 slice was taken randomly which represented the parts from whole body of the fish. Salt crystal were removed from sun dried salted fishes and mixture of Salt and turmeric were removed from turmeric treated sun dried salted product by tissue paper. Then the slices were chopped with skin and bone and finally ground with an electric blender to make a homogenous sample before being sampled for analysis.

\subsection{Proximate composition analysis:}

Proximate compositions of fish were determined by conventional method of AOAC (Association of Official Analytical Chemicals) on weight basis [19].

2.7.1. Estimation of moisture: About 5 gram of previously prepared fairly minced samples were taken into each known weight basin and weighed in a digital balance (Toledo, Switzerland). The samples were allowed to dry into the oven (Memmet 854 Schwabach) at $105^{\circ} \mathrm{C}$ for 24 hours in order to remove the moisture until constant weight. After that, the basins are taken out of the oven, cooled in a desiccators and were weighed in a digital balance.

Calculation

$$
\% \text { of Moisture }=\frac{\text { Weight Loss }}{\text { Original Weight of Sample Taken }} \times 100
$$

2.7.2. Estimation of protein: The protein content of the fish was determined by micro-kjeldahl method [20]. It involves conversion of organic nitrogen to ammonium sulphate by digestion with concentrated sulphuric acid in a microkjeldahl flask. The digest was diluted, made alkaline with sodium hydroxide and distilled. The liberated ammonia was collected in a boric acid solution and was determined titrametrically.

Calculation

$$
\% \text { of } \mathrm{N}_{2} \text { (titration reading - blank reading) } \times \text { strength of acid } \times 0.002 \times \frac{100}{5} \times 100
$$

\section{weight of sample taken}

For most routine purposes the percent of protein in the sample is then calculated by multiplying the $\%$ of $\mathrm{N}_{2}$ with an empirical factor of 6.25 for fish.

$\%$ of protein $=\%$ of total $\mathrm{N}_{2} \times 6.25$

2.7.3. Estimation of fat: About $5 \mathrm{~g}$ of the homogenous sample was taken into conical flasks and $10 \mathrm{ml}$ of folch reagent (Chloroform: Methanol $=2: 1$ ) was added into the sample and homogenized properly and kept in airtight condition for 24 hours. Fat contents of the fish muscle react with that solvent and remains in the solution. After 24 hours the solution of the flask was filtered in another weighed conical flask through a filter paper. Then these flasks were given in a hot water bath to dry up and removed the solvent. After that the flasks were kept into an oven for an hour to get the actual fat content. Then the flasks were weighed in an electronic balance to get the amount of fat content.

Calculation

$$
\% \text { of Fat }=\frac{\text { Weight of the residue }}{\text { Weight of sample taken }} \times 100
$$

2.7.4. Estimation of ash: About $4-5 \mathrm{~g}$ fish sample was weighed into a pre-weighed crucible. The crucible with the contents was heated first over a long flame till all the material was completely churned. Then it was transferred in the Muffle Furnace held at dark red at a rate of $600^{\circ} \mathrm{C}$ for 5 hours until the residue become white. The crucible were cooled in desiccators and weighed. Finally the $\%$ of ash content was calculated.

Calculation

$$
\% \text { of ash }=\frac{\text { Weight of fish }}{\text { Weight of sample taken }} \times 100
$$




\subsection{Estimation of $\mathrm{pH}$ :}

A $1 \mathrm{~g}$ sample of the fish flesh was homogenized in $10 \mathrm{ml}$ of distilled water and the mixture was filtered. The $\mathrm{pH}$ of the filtrate was measured using a pH meter (Mettler Toledo 320-s, Shanghi, China) [21].

\subsection{Statistical analysis:}

Data were analyzed by using SPSS for windows-20 statistical programme. Significance was established at $\mathrm{p}<0.05[22]$.

\section{Results And Discussion}

The bio-chemical composition (proximate composition and $\mathrm{pH}$ value) of fish is an important aspect in fish processing as influences both the keeping quality and the technological characteristics of the fish. The proximate composition (moisture, protein, fat and ash) and $\mathrm{pH}$ of Shoal fish in fresh condition as well as sundried-salted (SDS) and turmeric treated sun-dried-salted (SDS+T) condition were determined. The proximate composition of fish varied from species to species and even within the same species from one individual to another [23]. The body composition of fish seems to depend on sex, season and diet [24]. Starvation alters body constituents. Fat and protein are used as a source of energy, decreasing progressively during starvation while water content increases proportionally $[25,26]$.

Moisture, protein, fat, ash and $\mathrm{pH}$ value was $77.03 \%, 17.32 \%, 4.62 \%, 1.44 \%$ and 6.9 in case of fresh shoal fish respectively (Fig. 1). Fresh fish samples presented a high moisture and low protein content, similar to previously reported [27]. Fish species with low levels of fat are suitable to be processed [28].

Changes in proximate composition in sun-dried-salted and turmeric treated sun-dried-salted shoal fish products during different days of observation period through shelf life study were shown in Fig. 2 \& 3.

3.1. Moisture (\%): In case of SDS and SDS+T the decrease in moisture content become emphasize during the sun drying. This step which is normally combined with salting has duel effects such as the lowering of the water activity (aw) level and a specific inhibitory effect on the growth of some species of microorganisms through the $\mathrm{Na}+$ ion. So the two steps (Salting and Drying) are interrelated to reduce the moisture sufficiently. The decrease in moisture is due to osmotic migration of salt into and water out of the fish [29,30]. Decrease in moisture led to increase in salt content and consequently extend shelf life of the products [31,32].

In present experiment, moisture content was found $29.77 \%$ and $30.92 \%$ in freshly processed SDS and SDS+T shoal and after completing the duration of storage period, it was found 35.26\% (165 days) and 36.98\% (180 days) respectively (fig. $2 \& 3$ ).

In case of sun- dried salting and sun-dried salt +turmeric fish, significant reduction of moisture content was assumed to be increased due to action of salting and sunlight, because, the salt uptake consequently moisture loss is temperature dependent [33]. Similar opinion about the influence of air temperature in drying was described by [34]. They opined that even a small increase of only a few degrees in the intensity of sun-light may appreciably improve the over-all efficiency of the operation. This is certainly a surprising distinctive feature in this study. Fish dried after salting with 15 to $30 \%$ salt or brining in 9.5 to $15 \%$ brine solution for 18 hours showed higher degree of retention of all the materials than plain dried fish [35].

3.2. Protein (\%): The product with highest protein and fat content was referred to as a nutritious food. In general dried fish contains more nutrient than fresh fish [36]. Nutritionally dehydrated products are very good and neither the nutritive value nor the digestibility of the protein is adversely affected due to dehydration process $[37,38]$. Protein is the major nutrient factor contributed by animals to human diet. Fish is a major supplier of this factor. Fish as a source of protein supplies protein of high class quality compared to protein of other animal sources. Fish is however a highly bio-perishable material postmortem. Different technologies, including the two applied in this research have been used to preserve both the intrinsic and extrinsic qualities of fish soon after harvest. In this work therefore, an effort to find out which of these preservation methods; Sundried salting and turmeric treated Sun-dried salting, ensures better proximate composition and shelflife storage at Room Temperature $\left(27^{0}-30^{\circ} \mathrm{C}\right)$.

In SDS and SDS+T shoal fish products, protein content was found $41.48 \%$, and $41.0 \%$, in freshprocess condition and after completing the duration of storage period it was decreased into $38.62 \%$ (165 days) and 38.01 (\% (180 days) respectively (Fig $2 \& 3)$. The decrease of protein level was found to be significantly, proportional $(\mathrm{P}<0.05)$. Protein decreased with storage of cured meat and this was attributed to some changes during storage that caused by 'maillard reaction and changes in $\mathrm{pH}$ [39]. Salt causes the proteins in fish muscle to swell and salt lead the protein become denatured if increases in the muscle [40].

3.3. Fat (\%): Fat content was found to be influenced by season and geographic location [41]. In SDS and SDS+T shoal fish products, fat content was found $5.10 \%$, and $4.79 \%$, in fresh-process condition and after completing the duration of storage period it was 3.81\% (165 days) and 3.26 (\% (180 days) respectively (Fig. 2 $\& 3)$. It is clear from the present results that fat content was decreased significantly $(\mathrm{p}<0.05)$. This might be due 
to oxidative deterioration, thereby affecting lipid extraction [42].A decrease in the level of crude protein and fat of small and large salted Bouri fish muscle (Mugil cephalus)was found [43].

3.4. Ash (\%): In SDS and SDS+T shoal fish products, ash content was found $22.80 \%$, and $22.41 \%$, in freshprocess condition and after completing the duration of storage period it was found $21.44 \%$ (165 days) and 21.07 (\% (180 days) respectively (Fig. $2 \& 3$ ). The higher value of total ash content in freshly processed SDS and SDS+T shoal fish than fresh fish was attributed to high salt content. Similar levels of ash content in salted fish were noticed by several workers [44].

3.5. Changes in $\mathbf{p H}$ value: $\mathrm{pH}$ is an indicator of the extent of microbial spoilage in fish and some proteolytic microbes produce acid after decomposition of carbohydrate, thereby increasing the acid level of the medium [45]. The $\mathrm{pH}$ value is a reliable indicator of the degree of freshness or spoilage.

The $\mathrm{pH}$ in fresh condition fresh- water fish flesh is almost neutral [46]. In the post-mortem period, decomposition of nitrogenous compounds leads to an increase in $\mathrm{pH}$ in the fish flesh [47]. The increase in $\mathrm{pH}$ indicates the loss of quality. The $\mathrm{pH}$ value of SDS and SDS+T shoal and fish-product was increased significantly $(\mathrm{P}<0.05)$ with storage period. $\mathrm{pH}$ value of fresh Shoal fish was 6.9 in our study. But when salt is added with the fish, $\mathrm{pH}$ value decrease due to increase of acidic compound and after that among shelf life study $\mathrm{pH}$ value increases in the time interval due to increase of basic compounds. In the present study $\mathrm{pH}$ value were found to vary from 6.2 (0 day) to 8.3 (165 days) for SDS and 6.3(0 day) to 8.2 (180 days) for SDS+T Shoal (Fig. 4).

The fish products are acceptable up to a $\mathrm{pH}$ of 6.8 but are considered to be spoiled above $7.0 \mathrm{of} \mathrm{pH}$ [48]. 6.8 to 7.0 is usually the limit of acceptability [49]. While the initial $\mathrm{pH}$ values in the samples were similar to findings of other researchers, the increase in $\mathrm{pH}$ values during the storage of room temperature $\left(27-30^{\circ} \mathrm{C}\right)$ was higher than others. The probable reason of these differences is differences in fish species and different methods of salting.

\section{Acknowledgement}

The author acknowledges the scientists and technicians of Fish technology laboratory, IFST, BCSIR, Dhaka, Bangladesh for their technical supports and continuous assistance to carry out the present study.

\section{Conclusion}

The present study reveals that different fish drying methods have a significant role on the proximate composition of Shoal fish. It was observed that the hygienically dried samples using salt and salt- turmeric comparatively good nutritional value and textural aspects. Salt and turmeric is also useful to reduce the time of drying of fish. The saving of time and improvement of the quality in the dry fish process will help the poor Fisher folks getting better price for their products but also enhance consumer preference in the local market. In case, poor coastal people are not able to afford to have solar dryers, they can take this process of fish drying.

[1]. Srivastava, V.K. 1959. Limnological studies of freshwater bottom II. Qualitative composition and variation of the available food supply for fishes. Proc. Nat. Sci. India. 29:207-210.

[2]. Olomu, J.M. 1995. Monogastric Animal Nutrition. Jachem Publications, Benin City, Nigeria, pp: 165-200.

[3]. Kreuzer, R. and E. Heen, 1962. Fish Nutrition. London Fishing News Book Ltd., UK.,445pp.

[4]. Waterman, J.J., 1976. The production of dried fish. FAO Fisheries Technical Paper No. 160, Food and Agriculture Organization of the United Nations, Rome, Italy, pp: 115-120.

[5]. Frazier, W.C and Westerhoff, H.I. 1998. Food Microbiology. Tata MeGraw Hill Publishing Company Limited. New York. $243-252$.

[6]. Huss, H.H. Ababouch, L. and Gram, L. 2003. Assessment and management of seafood safety and quality. FAO Fisheries Technical Paper No. 444, FAO, Rome, 230pp.

[7]. Abraham, T.J. 2011. Food safety hazards related to emerging antibiotic resistant bacteria in cultured freshwater fishes of Kolkata, India. Adv. J. Food Sci. Technol.,3: 69-72.

[8]. Gram, L. and Dalgaard, P. 2002. Fish spoilage bacteria- problems and solutions. Curr. Opin. Biotech., 13: 262-266.

[9]. Paulsen, P. and Smulders, F.J.M. 2003. Combining Natural Antimicrobial Systems with other Preservation Techniques: The Case of Meat. In: Food Preservation Techniques, Zeuthen, P. and L. Bugh-Surensen 9Eds.) Woodhead Publishing Ltd., Cambridge, 71-85.

[10]. Awoyemi, M. D. and Eyo, A. A. 1998. Studies on the use of Salt, Vegetable Oil and Insecticide for Control of Dermestes maculates Infecting Dried Fish in Storage. FAO Fisheries Report, 574: 103 - 104.

[11]. Kreuzer, R. 1974. Fish and its place in culture. In: Fishery products (Kreuzer, R.Ed)FAO. 462pp.

[12]. Coulter, J.P. and Disey, J.G. 1987. The handling, processing and marketing of fish in Bangladesh. Overseas Development Natural Resources Institute (ODNRI), Bulletin No.1.

[13]. DOF (Dept. of Fisheries), 2005. Fisheries statistics Year Book of Bangladesh, 2004-2005, Published by the Dept. of Fishery, Matshya Bhaban, Dhaka. 42 pp.

[14]. Balachandran, K.K. 2001. Post harvest technology of fish and fish products. Daya Publishing house.1123/74, Delhi. 109-121.

[15]. Klaassen, C.D. Amdur, M.O. and Doull, J.A. 1986. Principles of Toxicology. In Casarett and Doull's Toxicology :The Basic Science of Poisons. New York: Macmillan.

[16]. Turan, H. Sonmez, G. Celic, M.Y. \& Yalcin, M. 2007. Effects of different salting process on the storage quality of Mediterranean Muscle (Mystus Galloprovincialis L. 1819) J. Muscle Foods, 18: 380-390.

[17]. Leroi, F. Joffraud, J.J. and Chevalier, F. 2000. Effect of salt and smoke on the microbiological quality of cold- smoked salmon during storage at 5 Degrees $C$ as estimated by the factorial design method. J. Food Prot. 63: 502-508.

www.iosrjournals.org 5 | Page


[18]. Raghunath, M.R. Sankar, M.R. Radhakrishnan, T.V. Suseela, M.A.G. Ammu, K. Ravishankar, C.N. Jayan,K. Leema, J.2000. Biochemical investigations on Antartic Krill, Ephausia superba. Fishery Technol. 37(1): 19-24.

[19]. AOAC. (Association of Official Analytical Chemist) 1990. Official methods of Analysis( $15^{\text {th }}$ ed.). Inc., Suite, 400, Arlington, Virginia. Vol.2: 685-1298 pp.

[20]. Pearson, D. 1999. Pearson's composition and analysis of foods. University of Reading.

[21]. Vynke W.1981. pH of fish muscle comparison of methods, Western European Fish Technologists' Association (WEFTA), Copenhagen, Denmark.

[22]. Sokal R. R. and Rohlf F. J.,1962. Introduction to biostatistics. New York: W. H. Freeman and Company, 1987, 363pp.

[23]. Stansby, M.E. Proximate Composition of fish. Fish in Nutrition. 55-61.

[24]. Graves, T.D.D. 1970. Body composition changes during growing in young sockeye (Oncorhynchus nerka) in fresh water. Bangladesh Journal fish research. Can. 27, 929-942.

[25]. Parker, R.R. and Vanstin, W.E. 1966. Changes in the chemical composition of central British Colombia pink salmon during early sea life. Bangladesh Journal of Fisheries Research. 23, 1353-1384.

[26]. Niimi, A.J. 1972.Changes in the proximate body composition of large mouth (Micropterus salmoides) under starvation. Jurnal of Zoology. 50, 815-819.

[27]. Eyo, A.A. 1998. Shelf-life of Moon fish (Citharinus citharus) and Tumk Fish (Mormyrus rume) During storage at ambient temperature and on Ice. FAO Fisheries Report No. 574, 35-37.

[28]. Mohammed, G.F. Hegazy, E.M. and Abdellatef, M. 2011. Physicochemical Properties and Mycootoxins contents of Tilapia FishFillets after Solar Drying and storage. Global Veterinaria J. 7(2), 138-148.

[29]. Horner, W.F.A. 1997. Preservation of fish by curing (drying, salting and smoking). In Fish Processing Technology. Blackie Academic \& Professionals, New York .31-71 pp.

[30]. Itou, K. and Akahane, Y. 2000. Changes in proximate composition and extractive components of rice- bran- fermented mackerel during processing.1051-1058.

[31]. Lopez, A. 1987. A complete course in canning Book: II and III, $12^{\text {th }}$ Ed. The canning Trade Inc. Baltimore USA.

[32]. Kingley- Ekow, G. 1999. A study of the effects of Handling, processing and storage on the histamine content in salted, fermented Tilapia, in M Phill, Ed. University of Ghana Legon Ghana.133 pp.

[33]. Duerr, J.D. and Dyer, W.R. 1952. Proteins in fish muscles denaturation by salt. J. Fish Res. Bd. Can 8: 325-329 pp.

[34]. Van Klaveren, F. W. and Legendre, R. 1965. Salted Cod. Fish as Food, ed. G. Borgstrom, Academic press. 3: 133 pp.

[35]. Nazir, D.J. and Magar, N.G. 1983. Chemical composition of mackerel and changes in the nutritive value during storage.Indian Food Technol. 1(6): 247.

[36]. Khuda, M.A.A. 1962. Chemical composition and quality of traditionally processed fish, Pak. J. Sci. Ind. Res., 5(2): 70-73.

[37]. Martenik, W.A. Jacobs, B. 1963. A new method for the determination of moisture in dehydrated vegetables. Proc. Inst. Food Technologist, 4th conf., 156pp.

[38]. Doha, S. 1964. Fish and shell fish preservation by sun and or air drying in some selected countries and the problem involve. J. Agric. Pak., 15(4): 455-477.

[39]. Lawrie, K.A. 1990 Meat science. $5^{\text {th }}$ ed. Program Press, Oxford. UK.

[40]. Hamm, R. 1994. Influence of pH on the protein net charge in the myofibrillar system. Rec. Meat Conf. Proc. 47, 5-9.

[41]. Agren, J.J. Al-Ahmed, H. and Hanninen, O. 1991. Fatty acid content and composition of five fish spesies in the Persian Gulf. Comp. Biochem. Physiol. 100B, 339-341.

[42]. Gandotra, R. Meenakshi, K. Sweta, G. Shallini, S. 2012. Change In Proximate Composition And Microbial Count By Low Temperature preservation In Fish Muscle Of Labeo rohita (Ham-Buch) IOSR J. Pharm. Biol. Sci. (IOSRJPBS) ISSN: 2278-3008 (July-August 2012). 2(1), 13-17.

[43]. El-Sebahy, L.A. and Metwalli, M.S. 1988. Changes in some chemical characteristics and lipid composition of salted fermented Bouri (M. cephalus)fish muscle. Food Chemistry. 31, 41-50.

[44]. Kiin-Kabari, D.B. Barimalaa, I.S. Achinewhu, S.C. Adeniji, T.A. 2011. Effect of extracts from three indigenous species on the chemical stability of smoke-dried catfish (Clarias lezera) during storage. Afr. J. Food Agric. Nut. Develop. 11(6), 5335-5343.

[45]. Eyo A. A.1993. Traditional and improved fish handling, preservation and processing techniques. Paper presented at national workshop on fish processing storage, marketing and utilization.

[46]. Virta, S.2009. Bachelor's Thesis, Isolation and Identification of Rainbow Trout spoiling Microbiota. Biotechnology and Food Technology, Turku University of Applied Science. 8pp. (Unpublished).

[47]. Shenderyuk, V.I. and Bykowski, P.J. 1989. Salting and Marinating of fish. In: Seafood Resources. Nutritional Composition and preservation, Sikorski, Z.E.(Ed.) CRC Press Inc. Boca Raton, Florida.

[48]. Huss, H.H. 1988. Fresh Fish-quality and quality changes, FAO Fihs. Series 29, FAO DANINAQ, Rome. Italy. 132 pp.

[49]. Erkan, N. Tosun, S.Y. Ulusoy, S. and Uretener, G. 2011. The use of thyme and laurel essential oil treatments to extend the shelf life of bluefish (Pomatomus saltatrix) during storage in Ice. Journal für Verbraucherschutz und Lebensmittelsicherheit. 6(1), 39-48. 


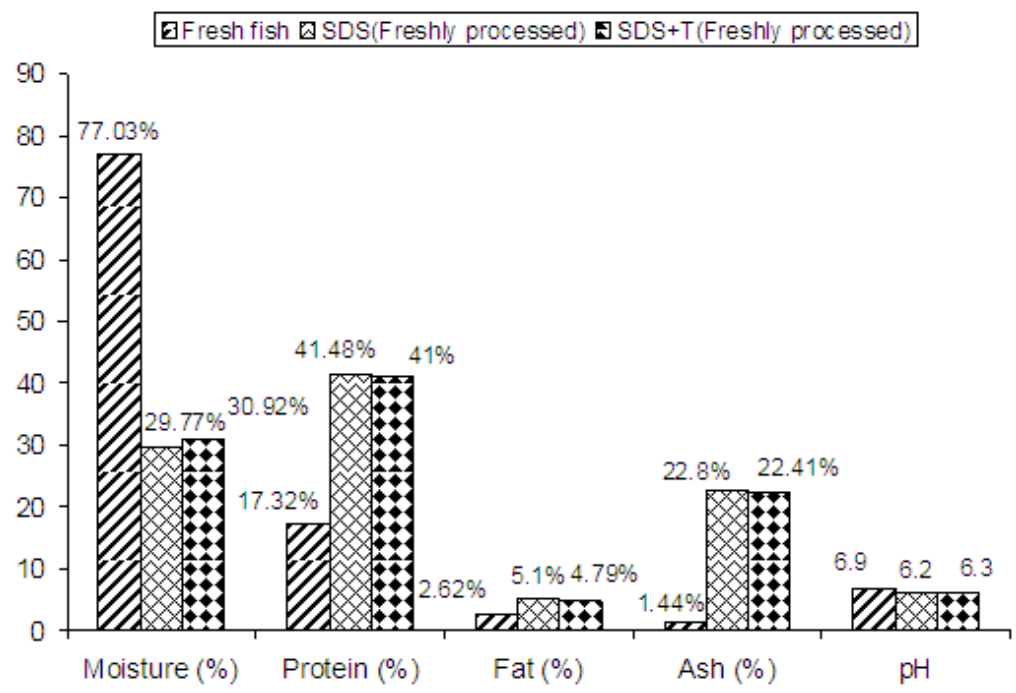

Figure.1. Initial proximate composition and $\mathrm{pH}$ value of the fresh experimental fish, freshly processed Sun-dried salted (SDS) and Turmeric treated Sun-dried salted (SDS+T) Shoal (Channa striatus).

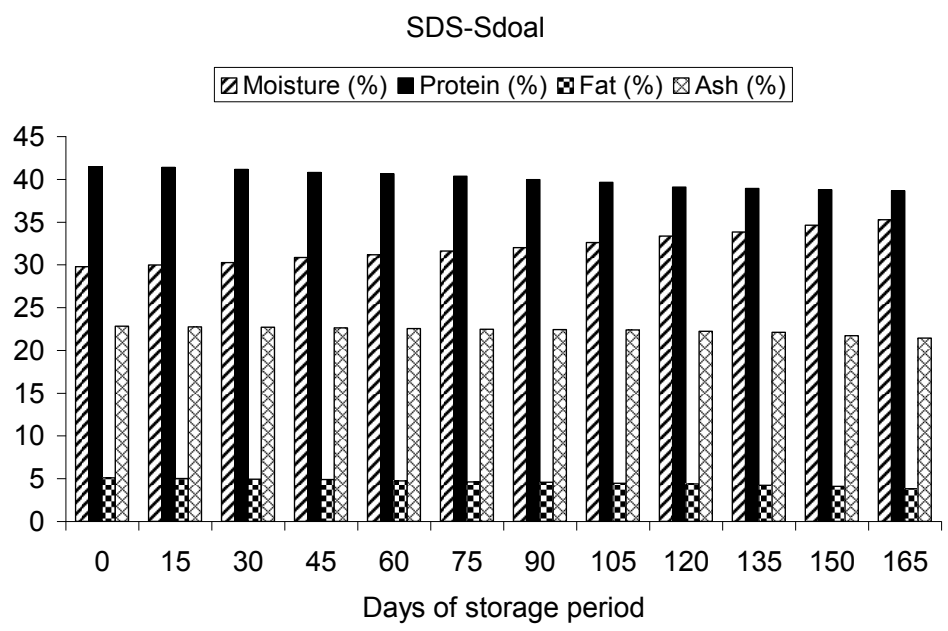

Figure. 2. Changes in Proximate Composition of Sun-dried-Salted (SDS) Shoal fish during Storage at Room Temperature.

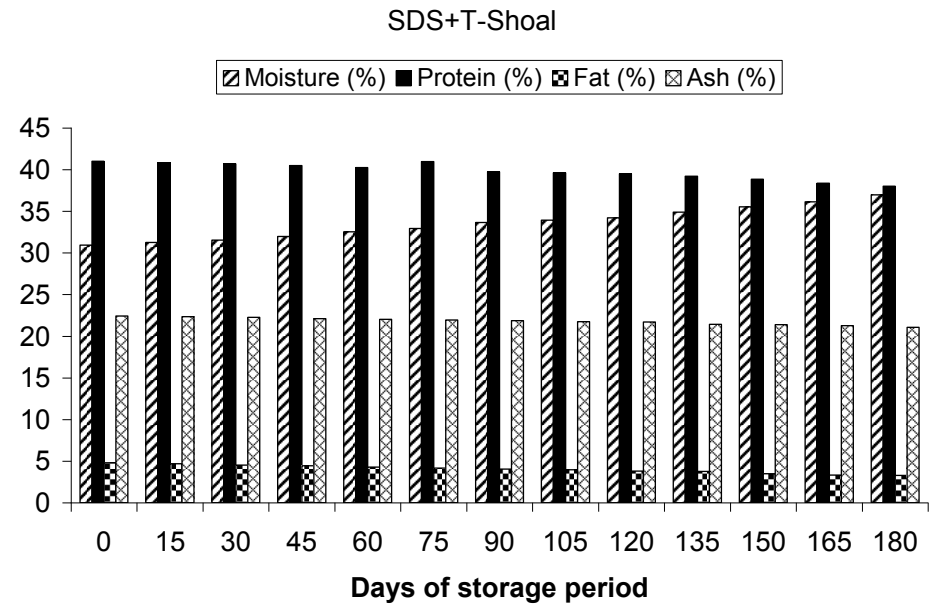

Figure. 3. Changes in Proximate Composition of Turmeric treated Sun-dried-Salted (SDS+T) Shoal fish during Storage at Room Temperature. 


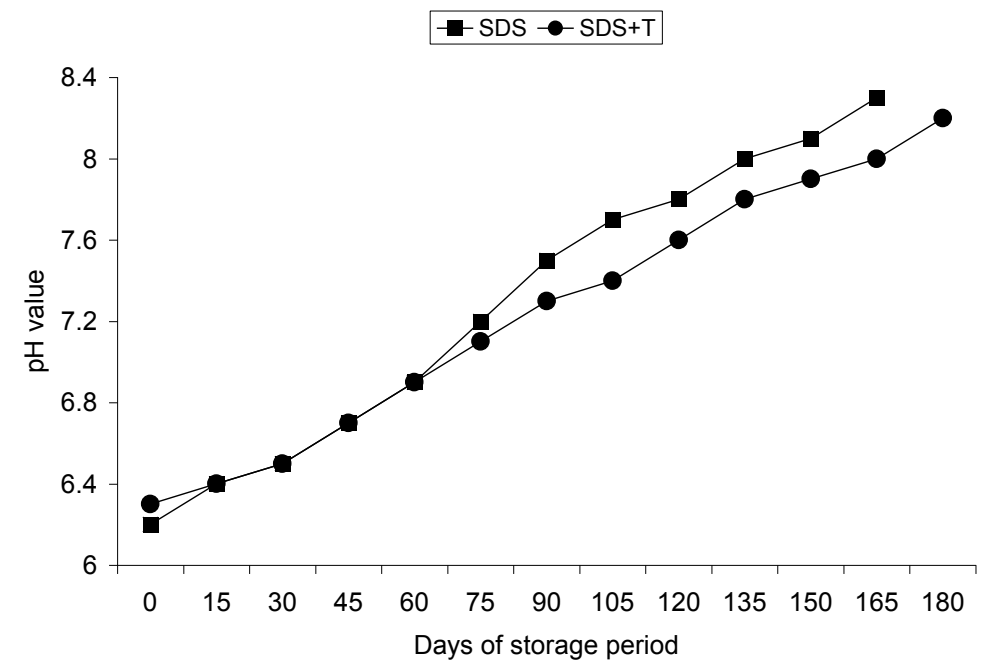

Figure. 4. Changes in pH value of Sun-dried-salted (SDS) and Turmeric treated Sun-dried-Salted (SDS+T) Shoal fish during Storage at Room Temperature. 